\title{
THE IMPORTANCE OF ANALYZING THE STRUCTURE OF THE LEGAL NORM IN ORDER TO INTERPRET AND TO APPLY CORRECTLY THE LAW
}

\section{R.D. VIDICAN}

\section{Roxana-Denisa VIDICAN, Candidate PhD.}

Faculty of Juridical and Administrative Sciences,Agora University of Oradea, Romania; Faculty of Law, Doctoral School, Titu Maiorescu University, Bucharest, Romania.

Correspondence: Roxana-Denisa Vidican, Agora University of Oradea, 8 PiaţaTineretului St., Oradea, Romania

E-mail: vidican.roxana@yahoo.com

\section{ABSTRACT}

In everyday life, people enter a multitude of social relationships with their peers. A social relationship turns into a legal relationship only if there is a legal norm that governs it. The law can not be conceived in the absence of the legal norm, so we can say that the legal norm is an essential element of the law.

KEY WORDS: legal norm, hypothesis, disposition, sanction

\section{INTRODUCTION}

Being an integral part of social norms, legal norms address human behavior. They are rules of conduct instituted or sanctioned by the state, the application of which is ensured by legal consciousness and, if necessary, by the coercive force of the state. ${ }^{1}$

The purpose of the legal norm is to ensure social cohabitation in the direction of promoting and consolidating social relations according to the ideals and values that govern the society. By means of legal norms, inter-human relations are regulated in specific forms. ${ }^{2}$

In the analysis of the structure of the juridical norm, we distinguish the logicaljuridical structure and the technical-legislative structure of the rule of law, respectively the internal structure, given by the way of its composition, and the external construction, given by the way of expression of the regulation within the normative act or another source of law. ${ }^{3}$

\section{THE LOGICAL-LEGAL (INTERNAL) STRUCTURE OF THE NORM}

The logical-juridical structure of the rule of law is of particular importance, as it indicates the elements of the norm and the interdependence between them.

This construction corresponds to the logical situation that any prescription to have the meaning and authority of a rule of law must prescribe the conditions under which certain categories of subjects will have a certain conduct (hypothesis), what is this conduct (disposition) and the consequences of non-compliance or violation (sanction).

\footnotetext{
${ }^{1}$ Gh. Boboş, C. Buzdugan, V. Rebreanu, Teoria generală a statului şi dreptului, Ed. Argonaut, Cluj-Napoca, 2008 , p. 334.

${ }^{2}$ L.R. Popoviciu, Elemente de drept: note de curs, Ed. Universităţii Agora, Oradea, 2007, p. 25.

${ }^{3}$ I. Santai, Introducere în teoria generală a dreptului, Ed. Risoprint, Cluj-Napoca, 2000, p.66.
} 


\section{Roxana-Denisa Vidican}

Irrespective of its textual formulation or the branch of law to which it belongs (constitutional, administrative, criminal, civil, international, etc.), the rule of law has a structure consisting of three elements: hypothesis, disposition, sanction.

1. The hypothesis is that part of the legal rule that prescribes the conditions under which the disposition is to be applied. It can be formulated in general or more specific terms. ${ }^{4}$ It provides, in abstract, the facts or legal acts that, when they occur and have a specific character, lead to the birth, modification or termination of a legal relationship. The hypothesis also indicates the categories of persons covered by the disposition.

Considering the precision with which the hypothesis of the legal norm is formulated, we distinguish determined hypotheses and relatively determined hypotheses.

A determinate assumption is that which sets out precisely the conditions under which the disposition rovision applies "the borrower can not, ahead of time, ask for the good borrower." ${ }^{5}$

A relatively determined (hypothetical) hypothesis exists when the mood conditions can not be formulated in all details, or not formulated, the hypothesis resulting from the context of the regulation. ${ }^{6}$ An example in this respect is art. 188 Criminal Code "The killing of a person is punished by imprisonment of 10-20 years and the prohibition of the exercise of certain rights". There is no indication of the circumstances of the person who committed the murder, in the place, time, and it is understood that no matter who does this deed and no matter what circumstances will be sanctioned by law. ${ }^{7}$

According to the degree of complexity of the circumstances under consideration, the hypothesis may be straightforward if it provides for a single circumstance in which the disposition applies or complex when it provides for a multitude of circumstances which all together or individually, determines the application of the disposition

Following the number of circumstances envisaged for the application of the rule, the hypothesis may be unique when only one circumstance has been foreseen to trigger the incidence of the law, or alternatively, a situation where several ways to achieve the law are foreseen. ${ }^{8}$

By the manner in which the terms of application are enunciated, the hypothesis may be generic when it provides for a particular genre or type of circumstance through which law is applied, or causal, when it lists, in a limitative or exemplary way, the circumstances in which the law applies. ${ }^{9}$

Whatever the norm, the hypothesis may be established, even if it is not expressly formulated, by answering the question "under what circumstances?" And "to whom?" The disposition of the legal norm will apply.

2. The disposition is the most important part of the legal norm and establishes the conduct to be respected under the circumstances and circumstances of the hypothesis. In other words, the disposition sets out the subjective rights and the corresponding obligations of the subjects covered by the legal norm. ${ }^{10}$

\footnotetext{
${ }^{4}$ Gh. Boboş, C. Buzdugan, V. Rebreanu, Teoria generală a statului şi dreptului, Ed. Argonaut, Cluj-Napoca, 2008 , p. 338.

${ }^{5}$ A. Sida, Introducere în teoria generală a dreptului, Cluj-Napoca,1996, p.119.

${ }^{6}$ L.R. Popoviciu, Elemente de drept: note de curs, Ed. Universităţii Agora, Oradea, 2007, p. 28.

${ }^{7}$ D. Moțiu, Teoria generală a dreptului, Cluj-Napoca,1996, p. 97.

${ }^{8}$ I. Santai, Introducere în teoria generală a dreptului, Ed. Risoprint, Cluj-Napoca, 2000, p.68.

${ }^{9}$ I. Santai, Introducere în teoria generală a dreptului, Ed. Risoprint, Cluj-Napoca, 2000, p.68.

${ }^{10}$ L.R. Popoviciu, Elemente de drept: note de curs, Ed. Universităţii Agora, Oradea, 2007, p. 28.
} 


\section{THE IMPORTANCE OF ANALYZING THE STRUCTURE OF THE LEGAL NORM IN ORDER TO INTERPRET AND TO APPLY CORRECTLY THE LAW}

The disposition may provide for the obligation to carry out certain actions, the obligation to refrain from action, as it may only permit, recommend or stimulate a wide range of human actions. ${ }^{11}$

According to the manner in which the subjects comply with the prescribed conduct, we distinguish between onerous dispositions - which require the obligation to carry out certain prohibitive actions - which prohibit the permissive actions - neither impose nor prohibit the actions, but leave to the parties to choose the conduct they want to follow (a variety of permissive disposition are suppliative dispositions that leave it to the stakeholders to choose the conduct they want to follow, and if they do not decide on the conduct, their will will be filled by the competent state bodies), recommendations - as a rule, review a certain conduct that the state recommends to social, incentive organizations - disposition reward for a special conduct, especially in the work process. ${ }^{12}$

By their degree of generality, we distinguish between general dispositions - they have a broad scope, usually referring to a branch of law, special dispositions - refer to a certain category of relations in a branch of law, exceptional dispositions - which have the role of protecting more effectively a range of social values, coming to complement the general or special dispositions.

According to the mode of determination of the conduct of the subjects of law, the provisdisposition ion can be determined or relatively determined. It is determined when determining precisely the conduct to be followed by the parties to the legal relationship, as is the case with onerative and prohibitive dispositions. When the rule provides for several possible variants of behavior, the subjects are to choose one, or set certain limits, within which legal rights and obligations can be established, the disposition is relatively determined, as is the case with permissive dispositions.

3. The sanction is the element of the legal norm that specifies the consequences of non-compliance. ${ }^{13}$ It is the consequence of acts of violation of law, violation and destabilization of the established order, aimed at restoring the violated order of law, repairing it and preventing its violation in the future, and contains the measures taken against the person who violated the law and which, if necessary, fulfilled by the coercive force of the state.

Sanctions are enforced by specially empowered bodies and is aimed at repairing the damage and restoring the violated order ${ }^{14}$, preventing violations of the rule of law in the future, punishing and re-establishing the culprit, and reintegrating it into society.

According to the legal nature of the breached name, we distinguish: criminal sanctions (applies to the offense committed), administrative sanctions (applicable for committing offenses, eg fine), disciplinary sanctions in the case of deviations from the labor discipline, eg reprimand, warning, termination of the employment contract), civil sanctions (consist of compensation for the person responsible for causing damage, or reinstatement, execution in kind, annulment of the unlawful act).

\footnotetext{
${ }^{11}$ Gh. Boboş, C. Buzdugan, V. Rebreanu, Teoria generală a statului şi dreptului, Ed. Argonaut, Cluj-Napoca, 2008, p. 339.

${ }^{12}$ D. Moţiu, Teoria generală a dreptului, Cluj-Napoca, 1996, p. 97, 98

${ }^{13}$ Gh. Boboş, C. Buzdugan, V. Rebreanu, Teoria generală a statului şi dreptului, Ed. Argonaut, Cluj-Napoca, 2008, p. 345

${ }^{14}$ L.R. Popoviciu, Elemente de drept: note de curs, Ed. Universităţii Agora, Oradea, 2007, p. 29
} 


\section{Roxana-Denisa Vidican}

According to their purpose, sanctions may be reparatory (ie reparation or compensation for the damage caused), coercive or repressive (ie coercive on the guilty person), penalties for annulment or termination of the act of nullity. ${ }^{15}$

According to the degree of determination, the sanctions are of several kinds: absolutely determined (those precisely formulated sanctions that can not be reduced or increased by the enforcement organs), relatively determined (they are set within the limits of a minimum and a maximum, and the sanction concrete, precise, to determine the enforcement body), alternatives (allow the enforcement body to choose between two or more types of sanctions, usually between imprisonment or fine), cumulative (establish several types of sanctions for the same deed ). ${ }^{16}$

According to their content, sanctions can be patrimonial (pecuniary, refers to the goods and income of the sanctioned person) and non-property (personal, directly and exclusively target the guilty person).

\section{THE TECHNICAL - LEGISLATIVE STRUCTURE}

The technical-legislative (external) structure refers to the form of expression of the content and its logical structure, when it is drafted.

The legal norm is not elaborated and does not appear distinct but as a rule part of a normative act that can take several forms (law, decision, ordinance, regulation, etc.) according to the authority that issued it.

In turn, regardless of the form under which it appears, the normative act is structured in chapters, sections, articles and paragraphs. The basic element of the normative act is the article that usually contains a standalone provision. However, not every article coincides with a rule of conduct. There are situations in which an article contains several rules of conduct or, to the contrary, an article may contain only one element of the legal norm (in this situation, in order to determine the content of the rule with all its logical-juridical elements it is necessary to corroborate more articles).

The technical - legislative structure of the norm does not always overlap with its logical - juridical structure, which is why, on the doctrine, some authors have supported an atypical construction of the legal norms in the respective branch. Thus, in the field of criminal law, there are authors who consider that the rules of criminal law contain only the provision and the sanction. Such a point of view can not be accepted because the criminal law rules contain all three elements only that they can be identified by a logical interpretation, in each case, of all the provisions of the Criminal Code - both a general part and a special part.

Generally, the legal rule brings together the three elements in the legal formulation of the legislative test. In many cases, however, the legal rule does not include all three constituent elements arranged in such a structure, for example, it may first foresee the sanction and then the hypothesis and disposition (as in the case of contraventional rules). In other situations, an element of the norm, such as sanction, as in the case of most constitutional norms (which, as a rule, only basic guiding principles and rules for other branches of law), may be missing. ${ }^{17}$

\section{CONCLUSIONS}

\footnotetext{
${ }^{15}$ I. Santai, Introducere în teoria generală a dreptului, Ed. Risoprint, Cluj-Napoca, 2000, p.69

${ }^{16}$ D. Moţiu, Teoria generală a dreptului, Cluj-Napoca, 1996, p. 99, 100

${ }^{17}$ I. Santai, Introducere în teoria generală a dreptului, Ed. Risoprint, Cluj-Napoca, 2000, p.70, 71
} 
Any legal norm presents content and form, each with its own way of expression. The content, consisting of hypothesis, disposition and sanction, is the internal structure of the legal norm, while the form is its external structure, by drafting that content, which may appear as an article, group of articles, or a determined normative act.

It is desirable that the assumptions be as concrete and complete as possible, which is a guarantee of the application of the provision, a measure to prevent arbitrariness and to strengthen the legality. Therefore, sometimes, after the adoption of the law, the legislative body intervenes to determine the limits of a more precise setting of the hypothesis of norms which are of particular importance for the realization of the law order in a certain area.

The relationship between the logical-juridical structure and the technical-legislative structure must be well understood because different ways of misinterpreting and applying the law would otherwise arise. This situation is more particular especially in the case of the rule, it lacks one or more elements of the structure and its retrieval must be made in the same or in other normative acts or even deduced from the same norm or from other legal formulations.

\section{BIBLIOGRAPHY}

1. Gh. Boboş, C. Buzdugan, V. Rebreanu, Teoria generală a statului şi dreptului, Ed. Argonaut, Cluj-Napoca, 2008.

2. L.R. Popoviciu, Elemente de drept: note de curs, Ed. Universităţii Agora, Oradea, 2007.

3. I. Santai, Introducere în teoria generală a dreptului, Ed. Risoprint, Cluj-Napoca, 2000.

4. A. Sida, Introducere în teoria generală a dreptului, Cluj-Napoca, 1996, p.119.

5. D. Moțiu, Teoria generală a dreptului, Cluj-Napoca, 1996. 